dr Željko Bjeljac

Geografski institut ,Jovan Cvijić“ SANU, Beograd

dr Nevena Ćurčić

Univerzitet u Novom Sadu, Prirodno-matematički fakultet, Departman za geografiju, turizam i hotelijerstvo

dr Jovana Brankov, dr Ana Milanović Pešić

Geografski institut ,Jovan Cvijić“ SANU, Beograd

UDK 338.48-53:79(497.113)

\title{
TRADICIONALNE SPORTSKE IGRE U VOJVODINI (SRBIJA) U FUNKCIJI DIVERZIFIKACIJE TURISTIČKOG PROIZVODA
}

\author{
TRADITIONAL SPORTS GAMES IN VOJVODINA IN THE FUNCTION \\ OF DIVERSIFICATION OF TOURISM PRODUCT
}

\begin{abstract}
Apstrakt: Tradicionalne sportske igre su izraz narodnog stvaralaštva $u$ domenu sporta $i$ rekreacije, rezultat kreativnosti naroda $u$ sportskoj kulturi. Prema prostoru održavanja najviše su vezane za ruralne sredine iz kojih su i potekle. Tradicionalne sportske igre su u XXI veku prepoznate kao element nematerijalnog kulturnog nasleđa, koje treba štititi i afirmisati na jedan nov način kako bi se sačuvale od zaborava $i$ nestajanja. Stoga se $u$ turističkim strategijama $i$ planovima $u$ svetu sve više prepoznaje značaj tradicionalnih sportova kao elementa turističke ponude (važan element turističke ponude i promocije ruralnog, verskog, kulturnog, sportsko-rekreativnog i manifestacionog turizma). Predmet istraživanja u radu je 16 manifestacija koje promovišu tradicionalne sportske igre $i$ veštine na teritoriji Vojvodine. Cilj rada je da se putem turizmološke valorizacije izdvoje oni stari tradicionalni sportovi koji mogu da predstavljaju važan segment $u$ diverzifikaciji turističkog proizvoda. U radu su korišćene analitičko-sintetička i induktivno-deduktivna metoda uz primenu kritičkog zaključivanja, kao i metoda turizmološke valorizacije prema Hilary du Cros.
\end{abstract}

Ključne reči: tradicionalne sportske igre, manifestacije, turistički proizvod, diverzifikacija, Vojvodina
Abstract: Traditional sports games are an expression of folk creativity in the field of sports and recreation, the result of the creativity of the people in the culture of sport. According to the venue, they are mostly related to the rural areas from which they originated. Traditional sports games were recognized in the 21st century as an element of intangible cultural heritage, which should be protected and affirmed in a new way in order to preserve them from oblivion and disappearance. Therefore, the importance of traditional sports as an element of tourist offer (an important element of tourist offer and promotion of rural, religious, cultural, sports and recreational tourism) is increasingly recognized in tourism strategies and plans in the world. The subject of this research is 16 events that promote traditional sports games and skills in the territory of Vojvodina. The aim of the paper is to distinguish old traditional sports through tourism valorisation, which can represent an important segment in the diversification of tourism products. The methods used are analytical-synthetic and inductive-deductive methods with the use of critical inference, as well as methods of tourism valorization according to Hilary du Cros.

Keywords: traditional sports games, manifestations, tourist product, diversification, Vojvodina 


\section{Uvod}

Sport i turizam predstavljaju u svetskim razmerama veoma važne aktivnosti koje su međusobno povezane i kompatibilne (zabava, rekreacija, sportska takmičenja). Svi današnji moderni sportovi su se razvili na osnovi ranijih sličnih sportova iz različitih vremenskih epoha. Tokom ranijih epoha razvile su se različite sportske igre i veštine, koje danas čine nasleđe iz prošlosti i izraz su narodnog stvaralaštva u domenu sporta i rekreacije. Mnoge tradicionalne igre i zabave podrazumevale su „aktivno učestvovanje svih prisutnih, $s$ ciljem uspostavljanja $\mathrm{i}$ učvršćenja zajedničkih vrijednosti, u interesu održavanja zajednice sa što većim stepenom društvenosti. Time, takvi oblici zabave istovremeno su zauzimali i vrijeme obaveze i slobodno vrijeme, ujedno spojeni rekreativnim i relaksacionim karakterom" (Božović, 2008, 98).

„Početkom 1970-ih došlo je do oživljavanja tradicionalnih oblika sporta, igara, plesa i rekreacije. Tokom perioda društveno-ekonomske i kulturne nesigurnosti, prošlost se često koristi kao spasonosna utopija. To je svojevrsni pokret - povratak korenima“" (Renson et al., 1997, 60). Igranje, uključujući i sportske igre, je osnovni element ljudskog društvenog postojanja i ponašanja. To su sportske igre koje predstavljaju izvornu fizičku aktivnost, koja za cilj ima jačanje fizičke i duhovne snage čoveka (Cvetković, 1982).

Iako je globalno širenje i popularizacija modernog sporta dovela do zapostavljanja tradicionalnih sportskih igara i njihove marginalizacije, a ponegde i gašenja i gubitka za lokalnu sredinu, bitni pomaci su ipak napravljeni i aktivnostima na oživljavanju tradicionalnih sportova se ozbiljno pristupilo. Međunarodna stručna javnost je prepoznala vrednost tradicionalnih sportskih igara i učinila važne korake u pravcu njihovog očuvanja i oživljavanja širom sveta. Ove aktivnosti su motivisane ne samo potrebom da se takvi sportovi i igre očuvaju u rastućoj svetskoj globalizaciji i opštoj komercijalizaciji savremenih sportova, već i da se sačuvaju tradicionalne etičke vrednosti i pravila fer-pleja koja su bila sastavni deo ovih igara. Takođe, tradicionalne sportske igre su našle svoje mesto i u turističkoj ponudi kao segment složenih turističkih proizvoda, u vidu tradicionalnih manifestacija nacionalnog i međunarodnog značaja.

Predmet istraživanja ovog rada su manifestacije koje promovišu i afirmišu tradicionalne sportske igre $\mathrm{i}$ veštine na teritoriji Vojvodine, njih 16. Zadatak rada je da se sagleda njihov turistički potencijal i uključenost u turističku ponudu. Cilj rada je da se turizmološkom kategorizacijom i klasifikacijom izdvoje oni stari tradicionalni sportovi (manifestacije) koji mogu da predstavljaju važan segment u diverzifikaciji turističkog proizvoda.

\section{Pregled literature}

U inostranoj i domaćoj naučnoj i stručnoj literaturi koriste se različiti pojmovi i definicije za stare sportove: narodne igre (folk games) (Eichberg, 1995; Bale, 2003), tradicionalni etnički sportovi (traditional ethnic sports) (Sogawa, 2006; Hajra, 2015), stari sportovi (Cvetković, 1982), tradicionalne narodne sportske igre i veštine (Bjeljac, Curčić, 2017), tradicionalne sportske igre (traditional sport games) (Rensonet al., 1997; Bronikowskaet al., 2014; Linaza et al., 20132015), tradicionalni sportovi i igre (traditional sports and games) (http://www.unesco. org/new/en/social-and-human-sciences/ themes/physical-education-and-sport/traditional-sports-and-games/).

Pojam tradicionalne sportske igre (traditional sport games) u svetskoj naučnoj $\mathrm{i}$ stručnoj literaturi se najviše koristi, te će autori taj termin zadržati i koristiti u ovom radu. Postoji veliki broj podela i klasifikacija 
tradicionalnih starih sportova zasnovanih na vrstama sportova, periodu održavanja, geografskom prostoru održavanja, običajima i ritualima, polno-starosnoj strukturi i drugo (Bjeljac, Brankov, 2019; Craig, 2002; Edvards, 2002; Liponski 2003; Linaza et al., 2013-2015; Krasilnikov, 2006; Marjanović, 2003; Cvetković, 1982; Hajra, 2015; Renson et al., 1997).

Jedna od najzastupljenijih podela prema vrstama starih sportova i igara, a koja se pojavljuje u većem broju naučnih radova je sledeća: igre sa loptom, streljački sportovi, borilački sportovi, sportovi sa životinjama, lokomotorne igre, akrobatika, igre sa kuglom, bacačke igre (Renson et al., 1997; Bronkovska et al., 2014; Linaza et al., 20132015). J. Cvetković (1982, 15) izdvaja: „stari atletski sportovi; stari borilački sportovi; stari narodni sportovi; stari konjički sportovi; stari sportovi na vodi; stari zimski sportovi; stare narodne igre. Isti autor izdvaja i takmičarske igre bez korišćenja pomoćnih predmeta, takmičarske igre sa korišćenjem pomoćnih predmeta, takmičarske zimske igre sa korišćenjem pomoćnih predmeta, takmičarske igre sa korišćenjem životinja”.

Maja 1994. godine Evropski parlament donosi program za promociju tradicionalnog i regionalnog sporta (European traditional sports and games platform project). Godine 1978. doneta je povelja za Fizičko obrazovanje, fizičke aktivnosti i sport, a 2015. godine je dopunjena ${ }^{1}$. Na sastanku Ministara za sport i fizičko obrazovanje, održanom u Punta del Este (Urugvaj) 1999. godine, doneta je deklaracijasa ciljem promocije, zaštite i razvoja tradicionalnih sportova, koju prati izrada svetske liste tradicionalnih sportova i igara. Generalna skupština UNESCO je 2003. godine usvojila Konvenciju o zaštiti

1 Član 1. stav 15 „Raznolikost fizičkog vaspitanja, fizičke aktivnosti i sporta osnovna je karakteristika njihove vrednosti i privlačnosti. Tradicionalne i autohtone igre, plesovi i sport, izražavaju bogato svetsko kulturno nasleđe i moraju se zaštititi i promovisati.“ nematerijalnog kulturnog nasleđa, a 2006. godine usvojena je međunarodna platforma za promociju i razvoj tradicionalnih starih sportova. Do 2018. godine usvojeni sui drugi brojni dokumenti na nivou UNESCO, Evropske Unije, međuvladinih komiteta za fizičku kulturu i sport. (http://www.unesco. org/new/en/social-and-human-sciences/ themes/physical-education-and-sport/traditional-sports-and-games//) ${ }^{2}$.

\section{Tradicionalne sportske igre kao turistički proizvod}

Značaj tradicionalnih sportskih igara najviše se ogleda kroz sport i rekreaciju, kulturu (nematerijalno kulturno nasleđe), turizam, ali i kombinovano. U svetu postoji preko 3000 tradicionalnih sportskih igara (Liponski, 2003) koje jesu ili imaju potencijal da budu element turističke ponude.

$\mathrm{U}$ poslednjih dvadesetak godina pojavljuju se stalno nova mesta ili regioni kao poželjne turističke destinacije, koje privlače turiste svojim izuzetnim kulturnim atrakcijama (povezane sa materijalnom i nematerijalnom kulturnom baštinom) (du Cros, McKercher, 2015). Među najzastupljenije vidove turizma ubraja se upravo kulturni turizam, čime tradicionalne sportske igre dobijaju više na značaju kao segment nematerijalne kulturne baštine. Tradicionalna sportska takmičenja, koja promovišu tradicionalni način života i kulturno nasleđe, održavaju se isključivo u ruralnim sredinama, a plasiraju se najčešće kroz manifestacioni turizam (Bjeljac, 2010). U okviru organizacije

2 Postoji i nekoliko međunarodnih organizacija putem kojih se promovišu tradicionalne sportske igre: European Traditional Sport and Games Association; International Sport and Culture Association; Conseil International des Organisations de Festivals de Folklore et d'Arts Traditionnels; International Federation of Popular Sports; The Association For International Sport for All. 
TAFISA (The Association For International Sport For All) održavaju se festivali sportska takmičenja tradicionalnih sportskih igara. U Srbiji se u organizaciji Asocijacije „Sport za sve“ Beograda održava Festival tradicionalnih narodnih veština (www.sportzasvebeograd.rs/). U Kazahstanu (Nur Sultanu) je predviđeno da se 2021. godine održe Prve svetske tradicionalne sportske igre u okviru UNESCO saveta za tradicionalne sportove i igre (Khan, Tluehan, 2019).

Od 2008. do 2018. godine na Listu nematerijalnog kulturnog nasleđa UNESCO upisano je 28 tradicionalnih starih sportova i igara (www.unesco.org/new/en/social-and-human-sciences/themes/physical-education-and-sport/traditional-sports-and-games/). Najveći broj tradicionalnih sportskih igara sa liste UNESCO je lociran u zemljama srednje, južne i jugoistočne Azije. Skoro svi su povezani sa tradicijom i kulturom naroda koji žive na tim prostorima, njihovim načinom života. Uz sportove se prezentuju folklor, običaji, rituali, muzika, zanatstvo, oralna tradicija, te ove zemlje predstavljaju i atraktivne turističke destinacije kulturnog turizma, koje su veoma posećene.

Osim manifestacija koje promovišu tradicionalne stare sportove, a koji su na UNESKO listi, mogu se izdvojiti i one koje promovišu veoma stare sportove širom sveta i nisu na UNESCO listi, ali predstavljaju snažan element privlačenja turista i afirmišu posete turističkim destinacijama, poput Gaaelic igre (Devine, Devine, 2005); Škotske brđanske igre (Brewster et al., 2009); Pelota ${ }^{3}$ (Baskija, Španija) (Prabucki, 2014), Gatika (Indija) (Hajra, 2015), sportske igre Indijanaca u Severnoj i Južnoj Americi, Aboridžina u Australiji, nacionalnih manjina u Kini, Rusiji (Edwards, 2012; Krasilnikov, 2006).

Značajne su i manifestacije koje promo-

3 Boćanje, igra koja je raširena i na mediteranske države. Održavaju se takmičenja i u Srbiji (prostor naseljen stanovništvom poreklom iz Dalmacije). višu tradicionalne stare sportove i unapređuju ponudu same destinacije, iako originalno ne potiču sa datog prostora. Tako se u Srbiji sreću manifestacijekoje su vezane za: kapoieru (Hedegard, 2013; Bjeljac et al., $2018)^{4}$, klasično konjaništvo (Čačić et al., $2013)^{5}$, Karkpinar festival, poznat i kao pelivansko rvanje ${ }^{6}$.

„Nematerijalno kulturno nasleđe jeste ono što na najbolji mogući način reflektuje nacionalni identitet kao nešto jedinstveno i zajedničko za jednu naciju, a posebno je atraktivan element kulturne i turističke ponude jedne zemlje. Promocija etničkih i etnoloških elemenata, koje postaju jasne ikone destinacije, veoma je poželjna sa aspekta razvoja turizma“ (Bjeljac et al., 2015,60). Kao takvi svi navedeni tradicionalni stari sportovi predstavljaju i nacionalni kulturni i turistički brend, a oni koji su na UNESCO listi i svetski brend.

\section{Tradicionalni stari sportovi na teritoriji Vojvodine}

Tradicionalne sportske igre proistekle su iz dokolice i zabave, u pauzama tokom radova na pašnjacima i poljima, tokom čuvanja stoke, na prelima, poselima, saborima, crkvenim svetkovinama, vašarima i sl. Pravila

4 Kapoiera je afro-brazilska borilačka veština, kombinovana sa elementima plesa, akrobatike i muzike. U okviru karnevala u Rio de Žaineru (Brazil) predstavlja najznačajniji element turističke ponude. Predstavlja i element turističke ponude Novog Sada, tokom uličnog festivala „Dani Brazila“ u Novom Sadu.

5 Tradicionalna umetnost i praksa uzgoja, obuke i jahanja lipicanera, stigla iz Austrije. Na prostoru bivše Jugoslavije čuvene su ergele Lipik (Hrvatska), Lipica (Slovenija), Karađorđevo i Zobnatica (Srbija) koje su takođe poznate po ovoj vrsti konja i po brojnim konjičkim trkama, kao i vrstama odgoja i obuke jahanja.

6 Pored Turske, brojna takmičenja se održavaju na teritorijama gde je nekad vladala Osmanska imperija (Severna Makedonija, Bosna i Hercegovina, Srbija, Albanija). 
su prenošena usmeno, s "kolena na koleno".

Migracioni procesi su često zahvatali današnju teritoriju Republike Srbije, kao i današnji prostor AP Vojvodine (Bjeljac, Terzić, 2016). „Naselivši nove krajeve, kolonisti su prenosili svoj jezik, običaje i kulturu, što podrazumeva i oblike fizičkog vežbanja koje su upražnjavali. Njihovo vežbanje je bilo usmereno na veštinu rukovanja kopljem i mačem i na borenja (pesničenje i rvanje). Običan narod je imao svoje oblike nadmetanja: bacanje kamena, trčanje, rvanje, pesničenje, borbe sa kopljem, mačem. Pored navedenih održavala su se i takmičanja u brzini kao posebna vrsta nadmetanja.“ (Šiljak,2007, 99-100). Tokom XIX veka na teritoriji Vojvodine se organizuju i prva takmičenja, koja su obuhvatala nadmetanja i u streličarstvu, borbama na konjima, mačevanju. Održavala su se u Kaštelu u Ečki (Zrenjanin). Na takmičenju su učestvovali i učesnici iz drugih delova Austrougarske monarhije (Bjeljac, 2010).
U drugoj polovini XX veka, na prostoru bivše SFR Jugoslavije, jedan deo ovih igara i starih sportova je bio sastavni deo susreta sela, seoskih olimpijada, radničkih sportskih igara, jadranskih susreta i sl., kao deo masovnog rekreativnog sporta i zabave. Tek početkom XXI veka počinju da se posmatraju kao deo turističke ponude, koja može da unapredi i diversifikuje turistički proizvod pojedinih turističkih destinacija.

Cvetković (1982) i Marjanović (2005) na prostoru bivše Jugoslavije izdvajaju preko 50 različitih tradicionalnih sportskih igara, koje se organizuju u okviru 70 različitih manifestacija (Bjeljac, Brankov, 2019). $\mathrm{Na}$ teritoriji Srbije održava se 39 , a na prostoru AP Vojvodine 1 6takvih manifestacija (Tabela 1). Na osnovu dominantne aktivnosti ili koncepcije igara izvršena je podela manifestacija na :takmičenja u košenju žita; tradicionalne stare sportove sa životinjama; karakteristične stare sportove; narodni višeboj (Bjeljac, Brankov, 2019).

Tabela 1. Manifestacije posvećene tradicionalnimstarim sportovima u Vojvodini

\begin{tabular}{|c|c|c|c|c|c|}
\hline $\begin{array}{l}\text { Vrsta } \\
\text { manifestacije }\end{array}$ & Naziv manifestacije & $\begin{array}{l}\text { Mesto } \\
\text { održavanja }\end{array}$ & $\begin{array}{l}\text { Broj } \\
\text { posetilaca }\end{array}$ & $\begin{array}{l}\text { Mesec } \\
\text { održavanja }\end{array}$ & $\begin{array}{l}\text { Početna } \\
\text { godina } \\
\text { održavanja }\end{array}$ \\
\hline $\begin{array}{l}\text { Takmičenja u } \\
\text { košenju žita }\end{array}$ & $\begin{array}{l}\text { Dužijanca (takmičenje } \\
\text { risara) } \\
\text { Seljačka olimpijada } \\
\text { Vojvodine } \\
\text { Seljački parti } \\
\text { Seljačka olimpijada }\end{array}$ & $\begin{array}{l}\text { Žitna polja oko } \\
\text { Subotice }(1,2) \\
\text { Bačka Topola (3) } \\
\text { 1Mokrin }(4) \\
\text { Mol (5) }\end{array}$ & $\begin{array}{l}100000 \\
5000 \\
3000 \\
2000\end{array}$ & $\begin{array}{l}\text { Juli-avgust } \\
\text { Juli } \\
\text { Avgust } \\
\text { Juli }\end{array}$ & $\begin{array}{l}1911 \\
2014 \\
2019 \\
2017\end{array}$ \\
\hline $\begin{array}{l}\text { Tradicionalni } \\
\text { sportovi sa } \\
\text { životinjama }\end{array}$ & $\begin{array}{l}\text { Ovčarski dani } \\
\text { Ovčarski dani } \\
\text { Ovčarski dani } \\
\text { Ovčarski dani } \\
\text { Ovčarski dani }\end{array}$ & $\begin{array}{l}\text { Sakule (6) } \\
\text { Kumane (7) } \\
\text { Ležimir (8) } \\
\text { Obrovac (9) } \\
\text { Čurug (10) } \\
\end{array}$ & \begin{tabular}{|l|}
10000 \\
5000 \\
3000 \\
3000 \\
4000 \\
\end{tabular} & $\begin{array}{l}\text { Mart } \\
\text { Maj } \\
\text { Septem. } \\
\text { Apri } \\
\text { Maj } \\
\end{array}$ & $\begin{array}{l}1997 \\
2014 \\
2014 \\
2009 \\
2016 \\
\end{array}$ \\
\hline $\begin{array}{l}\text { Karakter- } \\
\text { istični stari } \\
\text { sportovi }\end{array}$ & Banatske šore & Tomaševac (11) & 20000 & Juli & 2001 \\
\hline
\end{tabular}




\begin{tabular}{|c|c|c|c|c|c|}
\hline $\begin{array}{l}\text { Takmičarske } \\
\text { igre i veštine } \\
\text { (narodni } \\
\text { višeboj) }\end{array}$ & $\begin{array}{l}\text { Lička olimpijada } \\
\text { Krajiški višeboj } \\
\text { Seleuški višeboj } \\
\text { Seoska olimpijada } \\
\text { Plemenske viteške igre } \\
\text { Vojvođanska olimpi- } \\
\text { jada starih sportova }\end{array}$ & \begin{tabular}{|l|} 
Apatin (12) \\
Banatsko Novo \\
Selo (13) \\
Seleuš (14) \\
Sefkerin (6) \\
Lovćenac (15) \\
Bačko Gradište (16)
\end{tabular} & $\begin{array}{l}10000 \\
10000 \\
5000 \\
2000 \\
5000 \\
300\end{array}$ & $\begin{array}{l}\text { Juli } \\
\text { Juli } \\
\text { Septem. } \\
\text { Maj } \\
\text { Septem. } \\
\text { Avgust }\end{array}$ & $\begin{array}{l}20102 \\
2010 \\
2016 \\
2001 \\
2010 \\
2010\end{array}$ \\
\hline
\end{tabular}

Izvori: (1) Bjeljac, Curčić (2009);(2) facebook.com/Du\%C5\%BEijanca;

(3) www.vajma.info/cikk/Backa-TopolaVojvodanska-seljacka-olimpijada;

(4) www.rtv.rs/zivot/magazin/seljackiparti-u-mokrinu;(5) Bjeljac, Brankov (2010);

(6) www.glasopova.rs/;(7) www.webinfo. rs/info/37-novi-becej/-ovcarstva-kumane;

(8) https://www.sremskenovine. co.rs/2018/09/odrzani-peti-ovcarski-dani/

(9) http://backapalankavesti.com/odrzaniovcarski-dani/;(10)www.facebook.com/ TooZabalj/posts//;

(11) Bjeljac, Curčić, (2017); (12) https:// www.apatin.org.rs/kalendar-desavanja/lickaolimpijada;

(13) tvrubin.rs/krajiski-viseboj-ubanatskom-velikom-selu/;

(14) www.alibunar.org.rs/novosti/seleuskiviseboj;(15) http://mojabackatopola.rs/maliidos/odrzane-plemenske-viteske-igre;(16) podaci dobijeni od Bečejskog udruženja mladih (2019).

\section{Metodologija istraživanja}

Da bi se utvrdila turizmološka vrednost tradicionalnih starih sportova na teritoriji AP Vojvodine, korišćena je modifikovana Hilary du Cros metoda turizmološke vrednosti kulturnog nasleđa (Du Cros, 2000; Du Cros, Mc Kercher, 2015; Bjeljac et al., 2014; Bjeljac et al., 2015).

\section{Veličina i struktura uzorka}

Za potrebe ovog istraživanja primenjen je poseban upitnik kako bi se izbegla bilo kakva subjektivnost. Anketiranje je obavljenona uzorku od 14 stručnjaka iz različitih oblasti relevantnih za ovu studiju. Te osobe su ili organizatori samih manifestacija ili su na neki indirektan način povezane sa nekom od manifestacija (iz lokalnih turističkih organizacija, institucija kulture, naučni istraživači). Među ispitanicima našli su se sledeći stručnjaci: tri organizatora manifestacija, tri turizmologa koja rade u turističkim organizacijama, dva kustosa u muzeju, jedan etnolog, kao i četiri naučna istraživača na polju turizma (troje iz Geografskog instituta „Jovan Cvijić“ i jedan sa Departmana za geografiju, turizam i hotelijerstvo u Novom Sadu). Tokom procesa izbora reprezentativnog uzorka posebna pažnja je posvećena tome da se osigura da svi stručnjaci poseduju znanje o barem jednoj manifestaciji starih sportova u Vojvodini. Istraživanje je sprovedeno tokom proleća i leta 2019. godine. Pored upitnika korišćeni su i sekundarni izvori podataka, naročito u delu koji se odnosio na ocenu indikatora sektora menadžmenta. $\mathrm{U}$ tom delu upitnika ispitanici nisu mogli u potpunosti da odgovore na sva pitanja, tako da su sekundarni izvori podataka detaljnije analizirani radi prikupljanja svih potrebnih podataka. 


\section{Model turističke valorizacije prema Hilary du Cros}

Iako postoji više različitih metoda turizmološkog vrednovanja i procene privlačnosti sadržaja destinacije za turiste do sada se najčešće koristio kombinovani kvantitativno-kvalitativni metod, dok je najdetaljniji metod za procenu potencijala kulturnih dobara dala Hilary du Cros (Stanojlović et al., 2010). Pošto je složen i zasnovan na velikom broju pokazatelja koji istražuju vrednost kulturnog dobra, smatra se prikladnijim i pouzdanijim. Hilary du Cros je u proces valorizacije destinacije uvela određene kulturno-turističke subindikatore i stepene njihove gradacije ( $\mathrm{Du}$ Cros, 2000). Glavni indikatori ovog metoda su turistički sektor (tržišna privlačnosti faktori od značaja pri formiranju turističkog proizvoda) i sektor menadžmenta kulturnih dobara (kulturni značaj i robusnost). Model je kompleksan, pošto vrednuje kako turistički, tako i sektor upravljanja kulturnim dobrima.

Za svaki analizirani subindikator turističkog sektora formirana je skala vrednovanja, pri čemu je ocenjivanje vršeno numerički. Subindikatori se rangiraju ocenama od 0 do 5, ali određeni pokazatelji imaju i niže raspone ocena (0-3, 0-4). Kasnije se procenjuje tržišna atraktivnost kulturnih dobara na osnovu zbira vrednosti svih subindikatora. Dobijena ukupna ocena tumači se na sledećoj skali: 0-20 (mala atraktivnost), 21-40 (srednja atraktivnost) i 41-60 (velika atraktivnost za razvoj turizma). Sektor upravljanja kulturnim dobrima uključuje dva subindikatora: kulturni značaj i robusnost. Zbirom njihovih ocena dobija se sveobuhvatna vrednost sektora upravljanja kulturnim dobrima. Dobijeni rezultat interpretira se na sledećoj skali: 0-20 (visoka osetljivost / mala kulturna vrednost), 21-40 (srednja osetljivost i kul- turna vrednost) i 41-60 (niska osetljivost / visoka kulturna vrednost).

$\mathrm{Na}$ osnovu sprovedene analize postavljena je „matrica tržišne privlačnosti /robusnosti“ koja se sastoji od 9 ćelija i označena je s $M(i, j),(i, j=1,2,3)$ (Tabela 2). Za svako kulturno dobro se određuje kojoj ćeliji pripada, u zavisnostiod ocene koju je dobilo u postupku bodovanja (Du Cros, 2000; Hadžić et al., 2005; Stanojlović et al., 2010, Миленковић, 2018). Ćelije su definisane na sledeći način:

$\mathrm{M}(1,1)$ visoka vrednost indikatora kulturna značajnost/robusnost i mala tržišna privlačnost;

$\mathrm{M}(1,2)$ visoka vrednost indikatora kulturna značajnost/robusnost i srednja tržišna privlačnost;

$\mathrm{M}(1,3)$ visoka vrednost indikatora kulturna značajnost/robusnost i velika tržišna privlačnost;

$\mathrm{M}(2,1)$ srednja vrednost indikatora kulturna značajnost/robusnost i mala tržišna privlačnost;

$\mathrm{M}(2,2)$ srednja vrednost indikatora kulturna značajnost/robusnost i srednja tržišna privlačnost;

$\mathrm{M}(2,3)$ srednja vrednost indikatora kulturna značajnost/robusnost i velika tržišna privlačnost;

$\mathrm{M}(3,1)$ mala vrednost indikatora kulturna značajnost/robusnost i mala tržišna privlačnost;

$\mathrm{M}(3,2)$ mala vrednost indikatora kulturna značajnost/robusnost i srednja tržišna privlačnost;

$\mathrm{M}(3,3)$ mala vrednost indikatora kulturna značajnost/robusnost i velika tržišna privlačnost; 
Tabela 2. Matrica tržišne privlačnosti i robusnosti

\begin{tabular}{|l|l|l|l|l|}
\hline Indikator & \multicolumn{4}{|c|}{ Tržišna privlačnost } \\
\hline \multirow{3}{*}{ Robusnost } & Ukupna ocena & $0-20$ & $21-40$ & $41-60$ \\
\cline { 2 - 5 } & $0-20$ & $\mathrm{M}(3,1)$ & $\mathrm{M}(3,2)$ & $\mathrm{M}(3,3)$ \\
\cline { 2 - 5 } & $21-40$ & $\mathrm{M}(2,1)$ & $\mathrm{M}(2,2)$ & $\mathrm{M}(2,3)$ \\
\cline { 2 - 5 } & $41-60$ & $\mathrm{M}(1,1)$ & $\mathrm{M}(1,2)$ & $\mathrm{M}(1,3)$ \\
\hline
\end{tabular}

Izvor: Du Cros, 2000

Prilikom kreiranja turističkog proizvoda treba uzeti u obzir da najviše potencijala imaju kulturna dobra koja se, nakon izvršene turističke valorizacije, svrstavaju u ćelije $M(1,3)$ и $\mathrm{M}(2,3)$. S druge strane, kulturna dobra koja odlikuje mala tržišna privlačnost $\mathrm{M}(3,1)$ ne mogu se posmatrati kao atrakcije (destinacije) koje će privući veliki broj turista.

\section{Ocena turizmološke vrednosti} tradicionalnih starih sportova u Vojvodini

Turističke manifestacije predstavljaju širenje doživljaja, revitalizaciju tradicije, izgradnju lokalnog/nacionalnog ponosa, potvrđivanje grupa u zajednici, povećano učešće zajednice, uvođenje novih ideja i proširivanje kulturnih perspektiva, identitet zajednice, što je karakteristično i za multietnički prostor Vojvodine (Bjeljac, 2010). Rezultati valorizacije manifestacija koje su posvećene starim sportovima mogu biti od posebnog značaja za dalje razvijanje i bolje organizovanje turističke ponude svake pojedinačne destinacije u kojoj se manifestacija održava (Tabela 3 i 4).

Tabela 3. Turizmološka valorizacija tradicionalnih starih sportova prema Hilary du Cros metodi-ocena indikatora turističkog sektora

\begin{tabular}{|c|c|c|c|c|c|c|c|c|c|c|c|c|c|}
\hline $\begin{array}{l}\text { Indikatori } \\
\text { turističke } \\
\text { privlačnosti }\end{array}$ & 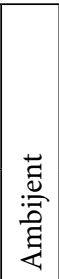 & 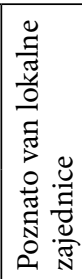 & 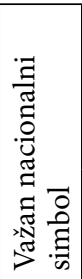 & 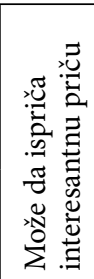 & 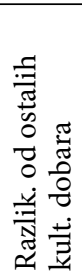 & 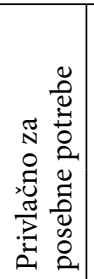 & 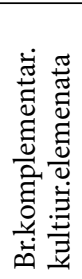 & 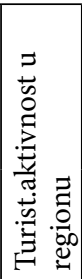 & 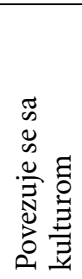 & 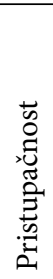 & 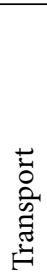 & 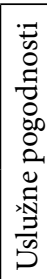 & $\frac{8}{2}$ \\
\hline Dužijanca & 5 & 5 & 5 & 5 & 5 & 5 & 3 & 5 & 5 & 3 & 3 & 5 & 54 \\
\hline $\begin{array}{l}\text { Seljačka olimpijada } \\
\text { Vojvodine Bačka } \\
\text { Topola }\end{array}$ & 1 & 2 & 1 & 3 & 3 & 2 & 2 & 2 & 1 & 3 & 3 & 3 & 26 \\
\hline Seljački parti & 1 & 1 & 1 & 2 & 2 & 1 & 1 & 3 & 1 & 2 & 2 & 2 & 19 \\
\hline $\begin{array}{l}\text { Seljačka olimpijada } \\
\text { Mol }\end{array}$ & 1 & 1 & 1 & 2 & 1 & 1 & 1 & 1 & 1 & 2 & 3 & 1 & 16 \\
\hline $\begin{array}{l}\text { Ovčarski dani } \\
\text { Sakule }\end{array}$ & 3 & 3 & 2 & 3 & 3 & 3 & 2 & 2 & 2 & 2 & 1 & 2 & 28 \\
\hline $\begin{array}{l}\text { Ovčarski dani } \\
\text { Kumane }\end{array}$ & 3 & 2 & 3 & 3 & 3 & 3 & 2 & 3 & 2 & 1 & 1 & 1 & 27 \\
\hline $\begin{array}{l}\text { Ovčarski dani } \\
\text { Ležimir }\end{array}$ & 2 & 1 & 1 & 1 & 1 & 2 & 1 & 2 & 1 & 1 & 1 & 1 & 15 \\
\hline
\end{tabular}




\begin{tabular}{|l|l|l|l|l|l|l|l|l|l|l|l|l|l|}
\hline $\begin{array}{l}\text { Ovčarski dani } \\
\text { Obrovac }\end{array}$ & 1 & 1 & 1 & 1 & 1 & 1 & 1 & 3 & 1 & 2 & 2 & 1 & $\mathbf{1 6}$ \\
\hline Ovčarski dani Čurug & 3 & 1 & 1 & 1 & 0 & 2 & 1 & 2 & 1 & 2 & 2 & 2 & $\mathbf{1 9}$ \\
\hline Banatske šore & 3 & 4 & 4 & 4 & 5 & 3 & 1 & 3 & 3 & 2 & 1 & 2 & $\mathbf{3 6}$ \\
\hline Lička olimpijada & 5 & 4 & 4 & 5 & 5 & 5 & 3 & 5 & 5 & 3 & 3 & 5 & $\mathbf{5 3}$ \\
\hline Krajiški višeboj & 3 & 3 & 4 & 4 & 3 & 3 & 2 & 2 & 4 & 3 & 2 & 3 & $\mathbf{3 6}$ \\
\hline Seleuški višeboj & 3 & 3 & 3 & 4 & 3 & 3 & 2 & 2 & 3 & 1 & 1 & 2 & $\mathbf{3 0}$ \\
\hline Plemenske viteške igre & 3 & 3 & 4 & 4 & 3 & 3 & 2 & 1 & 2 & 3 & 3 & 2 & $\mathbf{3 4}$ \\
\hline $\begin{array}{l}\text { Seoska olimpijada } \\
\text { Sefkerin }\end{array}$ & 2 & 2 & 1 & 2 & 2 & 1 & 1 & 2 & 1 & 1 & 1 & 1 & $\mathbf{1 7}$ \\
\hline $\begin{array}{l}\text { Vojvođanska olimpi- } \\
\text { jada starih sportova }\end{array}$ & 2 & 2 & 3 & 4 & 4 & 3 & 1 & 3 & 2 & 2 & 2 & 2 & $\mathbf{3 0}$ \\
\hline
\end{tabular}

Izvor: istraživanje autora

Dužijanca je manifestacija kojom se proslavlja tradicija, folklor i običaji tokom žetvenih svečanosti hrvatske nacionalne manjine i bunjevačke etničke grupe u Srbiji. Kao takva, poznata je van lokalne zajednice i predstavlja važan nacionalni, kulturni i verski simbol. Sa preko 30 različitih programa mogu se ispričati brojne priče. Takmičenje risara u košenju žita, folklor, običaji tokom obreda su jedan od važnijih elemenata proslave završetka žetve. Održava se i takmičenje u pucanju bičem ${ }^{7}$, konjičke trke, umetnička kolonija „Naiva u tehnici slame“, festivali folklora, izložbe domaće radinosti i dr., tako da manifestaciju prati veliki broj različitih komplementarnih aktivnosti. Sa svojim karakteristikama, kao jedinstvena manifestacija na destinaciji razlikuje se od ostalih kulturnih dobara. Ima značajno mesto u turističkoj ponudi kulturnog turizma, ne samo grada Subotice, već i Srbije, a komplementarna je i sa ostalom turističkom ponudom u regionu. Posećuju je turisti iz Srbije, Hrvatske, Mađarske.

Kao manifestacija koja proslavlja tradiciju, folklor i običaje tokom žetelačkih svečanosti mađarske nacionalne manjine u Srbiji izdvaja se Seljačka olimpijada Vojvodine (Bačka Topola). Održava se na/uoči mađarskog nacionalnog praznika Szent Is-

\footnotetext{
7 U Vojvodini pastiri koriste bičeve sa kratkom čvrstom drškom. Održavaju se i takmičenja ko bolje ume da ,puca“ bičem.
}

tván (Sveti Stefan). Takmičarske igre su vezane za rad na polju, uz zabavan karakter i donekle su i modernizovane: bacanje gumenih čizama, bacanje bala od slame u dalj, prevoženje džakova na biciklu, krunjenje kukuruza, prebiranje pasulja, trka traktora, trka tragačama ${ }^{8}$, uz izložbu narodne radinosti, poljoprivredne mehanizacije i sl. Nalazi se i u ponudi Turističke organizacije opštine Bačka Topola, ali nije dovoljno promovisana i nije komplementarna sa ostalom ponudom destinacije.

Posle Prvog i posle Drugog svetskog rata, na teritoriji Vojvodine izvršene su kolonizacije srpskog stanovništva sa prostora Hrvatske (Lika, Kordun, Banija, Dalmacija), Bosne i Hercegovine (Zapadna Bosna, Hercegovina) i Crne Gore (Durmitorski srez) (Bjeljac,Terzić, 2016). Uglavnom su naselili prostor severozapadne Bačke (iz Hrvatske), zapadne Bačke, srednjeg Banata (iz $\mathrm{BiH}$ ) i srednje Bačke (Crna Gora). Sa sobom su doneli brojne tradicionalne običaje i kulturno nasleđe. To se odnosi i na tradicionalne sportske igre, koje se pre svega zasnivaju na takmičarskim igrama i veštinama, poznate i kao narodni višeboj ${ }^{9}$.Lička olimpijada (Banja Junaković, opština Apatin), Krajiški višeboj (Banatsko Novo Selo, opština Kikin-

8 Ručna drvena kolica sa prečagama i jednim točkom.

9 U narodnoj umetnosti i mitologiji prepoznati su kroz epski, hajdučki i uskočki ciklus pesama, te se još organizuju i kao manifestacije hajdučke igre. 
da), Seleuški višeboj (Seleuš, opština Alibunar) i Plemenske viteške igre (Lovćenac, opština Mali Iđoš), predstavljaju manifestacije koje promovišu tradiciju, kulturu, folklor i običaje srpskog stanovništva doseljenog iz Hrvatske, Bosne iHercegovine i Crne Gore i komplementarne su sa turističkom ponudom regiona u kome se održavaju. Igre u višeboju su najčešće: trka u vrećama, vučenje kuke, skok udalj iz mesta, pretezanje štapa, hodanje po brvnu, obaranje ruku, skok uvis iz mesta, penjanje uz stožinu, bacanje kamena s ramena, nadvlačnjenje konopa. U Seleušu, osim navedenih, jedna od takmičarskih disciplina je i boćanje (balote). Takmičenja u boćanju se održavaju i na teritoriji $\mathrm{BiH}$, Hrvatske, Crne Gore i Srbije, čime takmičenje u Seleušu jeste važan nacionalni simbol i postalo je poznato van naše države. Osim sportskog dela, održavaju se večeri folklora, izložbe narodne radinosti, predstavljanje karakterističnih gastronomskih specijaliteta i zabavni program.Seleuški višeboj se nalazi u zvaničnoj turističkoj ponudi Turističke organizacije Alibunar. U okviru Seoske olimpijade u Sefkerinu, osim bacanja kamena s ramena i skoka udalj iz mesta, discipline su i trka u džakovima i streličarstvo. Turistička organizacija opštine Apatin je jedan od suorganizatora Ličke olimpijade, a lokacija održavanja su sportski tereni u okviru Banje Junaković. Jedan od pokrovitelja Plemenskih viteških igara u Lovćencu je i Vlada Crne Gore. Osim domaćih, na ovim takmičenjima učestvuju i ekipe iz bivšeg zavičaja, a kao posetioci dolaze i gosti iz Bosne i Hercegovine, Hrvatske i Crne Gore.

Vojvođanska olimpijada starih sportova u Bačkom Gradištu se organizuje sa „ciljem da oživi zaboravljene veštine kojima su pre par vekova mladići pokušavali da zadive svoje izabranice ili da pobede omladinu iz susednog sela“. Održava se na dan ili uoči seoske slave „Preobraženje“ (19. avgust). Prvih nekoliko godina olimpijade bilo je zastupljeno oko 30 disciplina tradicionalnih starih sportova, a danas ih je uključeno $18 .^{10}$

10 pilcike, ringlanje, trka na štulama, trka u
Uz ekipe iz Bačke, povremeno učestvuju i ekipe iz Mađarske i Hrvatske. Olimpijada starih sportova (Brođanci, Hrvatska) i Vojvođanska olimpijada starih sportova su jedine manifestacije koje se bave promocijom i očuvanjem većeg broja tradicionalnih starih sportova, igara i veština.

„Ovčarska proizvodnja u Vojvodini nema toliki ekonomski značaj za poljoprivredu Vojvodine, kao što to imaju svinjarstvo i govedarstvo. Proizvodni pokazatelji $\mathrm{u}$ ovčarstvu u Vojvodini beleže pozitivne rezultate. Visoke su godišnje stope rasta priplodnih grla i ukupnog broja grla, a i prosečan prirast po priplodnoj ovci pokazuje tendenciju porasta $(3,98 \%$ godišnje) što pokazuje da je ovčarstvo u Vojvodini u ekspanziji“ (Novaković et al., 2009, 48). Ovčarstvo ima dugu tradiciju gajenja, pre svega na prostorima južne Bačke i Banata i u novije vreme na Fruškoj gori. Ovčarske manifestacije uglavnom imaju lokalno-regionalni privredni značaj (izložba stoke, poljoprivrednih mašina i sl.), gastronomski značaj - jagnjeći specijaliteti, izložbe domaće radinosti, uz prateći zabavni program. Pojedine su deo i turističke ponude opština Opovo, Žabalj i Novi Bečej (Ovčarski dani Sakule, Čurug i Kumane). Kao tradicionalni stari sportovi izdvajaju se: takmičenje u šišanju ovaca, trka magaraca u Sakulama i ,svetsko prvenstvo u činganju" u Kumanu. ${ }^{11}$ Sve ove manifestacije se održavaju na sportskim terenima, u okviru stočnih vašara, a ovčarski dani u Čurugu na poljani pored „Rođine vetrenjače“, koja danas predstavlja vredan objekat industrijskog nasleđa Vojvodine.

Banatske šore ${ }^{12}$ imaju tradiciju održavanja

džakovima, streličarstvo, skok u dalj iz mesta, skok uvis iz mesta, pucanje korbačem, bacanje kamena s ramena, dragače, kozana, natezanje mosora, čočka, tokač, vranići, nadvlačenje klipa, vučenje kuke, krbanje.

11 Činga je stara pastirska igra, a sastoji se u tome da takmičari uz pomoć palica moraju baciti drvenu pločicu - čingu.

12 ,Šora“ ili lopta na beganje je stara pastirska igra, koja se igrala na utrinama, u pauzama čuvanja stada. Naziv potiče iz lokalnog banatskog slenga: ,,rašorati“, „zašorati“, ,„šornuti“ (udariti lopticu). 
dugu preko 200 godina (prema usmenom predanju). Nekada je ovaj sport bio rasprostranjen po celoj Vojvodini. Danas se održava kao ,Svetsko prvenstvo u banatskim šorama" samo u tri mesta: Tomaševac, Orlovat i Botoš (svi opština Zrenjanin). Banatske šore su 2013. godine u Sportskom savezu Srbije registrovane u kategoriji tradicionalni sportovi. Za šore se vezuje mit da je "Mihajlo Pupin po odlasku u SAD odneo i pravila šora i da je tako nastao bejzbol" (Bjeljac, Curčić, 2012, 6). Ipak, to je samo mit, jer je istorija bejzbola znatno starija. Ako se posmatra geneza i pravila i način igranja šora, u pojedinim evropskim državama se mogu naći veoma slične pastirske igre: Lapta (Rusija), Hurling (Irska), Méta (Mađarska), Oina (Rumunija), Pesäpallo (Finska), čime šore predstavljaju autentičan stari evropski sport (Stojaković, 2019; http://www.recallgames. com/games/7). Iako je turistička ponuda grada Zrenjanina veoma bogata i komplementarna, šore nisu deo njihove zvanične ponude.
Za skoro sve manifestacije je karakteristično da se nalaze relativno blizu u odnosu na velike turistički emitivne centre (Beograd, Novi Sad, Zrenjanin, Suboticu, Smederevo i dr.) i da su saobraćajno dobro povezane. Sve se nalaze na trasama važnih, međunarodnih drumskih i železničkih saobraćajnica. Jedino lokalni autobuski saobraćaj tokom trajanja pojedinih manifestacija nije pojačan, što može biti ograničenje u bržem transportu turista.

$\mathrm{Na}$ osnovu podataka u tabeli 3 može se utvrditi koje manifestacije starih sportova imaju visoku turističku atraktivnost. Najbolje ocenjene manifestacije su one koje su sakupile od 41-60 poena: Dužijanca (Subotica, 54 boda) i Lička olimpijada (Banja Junaković, 53 boda). Srednju privlačnost ima osam manifestacija,od kojih se po turističkoj privlačnosti izdvajaju: Banatske šore (Tomaševac, 36 bodova), Krajiški višeboj (Banatsko Novo Selo, 36 bodova) i Plemenske viteške igre (Lovćenac, 34 boda). Šest manifestacija ima nisku turističku privlačnost, pošto su ostvarile manje od 20 poena.

Tabela 4. Turizmološka valorizacija tradicionalnih starih sportova prema Hilary du Cros metodi-ocena indikatora sektora menadžmenta

\begin{tabular}{|c|c|c|c|c|c|c|c|c|c|c|c|c|c|c|}
\hline $\begin{array}{l}\text { Indikatori sek- } \\
\text { tora menadž- } \\
\text { menta }\end{array}$ & 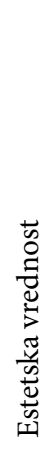 & 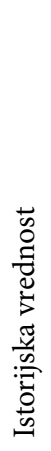 & 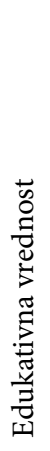 & 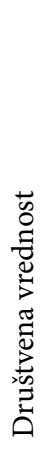 & 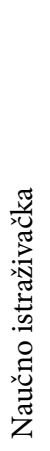 & 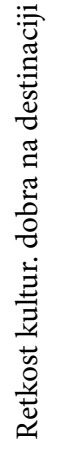 & 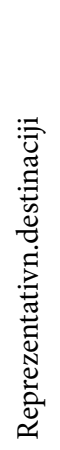 & 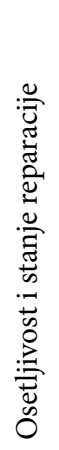 & 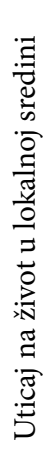 & 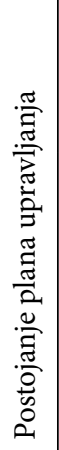 & 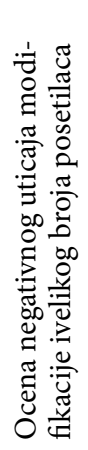 & 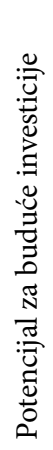 & 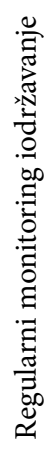 & 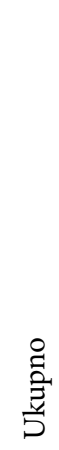 \\
\hline Dužijanca & 2 & 2 & 2 & 2 & 2 & 3 & 4 & 3 & 5 & 5 & 3 & 5 & 5 & 43 \\
\hline $\begin{array}{l}\text { Seljačka } \\
\text { olimpijada } \\
\text { Vojvodine }\end{array}$ & 1 & 1 & 1 & 2 & 1 & 2 & 2 & 2 & 3 & 3 & 3 & 2 & 2 & 25 \\
\hline Seljački parti & 1 & 0 & 0 & 2 & 0 & 1 & 0 & 2 & 2 & 1 & 2 & 2 & 1 & 13 \\
\hline $\begin{array}{l}\text { Seljačka olimpi- } \\
\text { jada Mol }\end{array}$ & 1 & 0 & 0 & 2 & 0 & 1 & 0 & 2 & 2 & 2 & 2 & 2 & 1 & 15 \\
\hline
\end{tabular}




\begin{tabular}{|l|c|c|c|c|c|c|c|c|c|c|c|c|c|c|}
\hline $\begin{array}{l}\text { Ovčarski dani } \\
\text { Sakule }\end{array}$ & 1 & 1 & 0 & 2 & 1 & 2 & 2 & 3 & 4 & 4 & 3 & 4 & 5 & $\mathbf{3 1}$ \\
\hline $\begin{array}{l}\text { Ovčarski dani } \\
\text { Kumane }\end{array}$ & 1 & 1 & 2 & 2 & 1 & 2 & 2 & 3 & 4 & 3 & 3 & 3 & 4 & $\mathbf{3 0}$ \\
\hline $\begin{array}{l}\text { Ovčarski dani } \\
\text { Ležimir }\end{array}$ & 1 & 0 & 0 & 2 & 1 & 0 & 1 & 2 & 2 & 3 & 3 & 2 & 3 & $\mathbf{2 0}$ \\
\hline $\begin{array}{l}\text { Ovčarski dani } \\
\text { Obrovac }\end{array}$ & 1 & 0 & 0 & 2 & 1 & 0 & 2 & 2 & 2 & 3 & 3 & 2 & 2 & $\mathbf{2 1}$ \\
\hline $\begin{array}{l}\text { Ovčarski dani } \\
\text { Curug }\end{array}$ & 1 & 1 & 0 & 1 & 1 & 0 & 1 & 3 & 2 & 3 & 3 & 4 & 3 & $\mathbf{2 3}$ \\
\hline $\begin{array}{l}\text { Banatske šore } \\
\text { Lička olimpijada }\end{array}$ & 1 & 2 & 1 & 2 & 2 & 3 & 3 & 2 & 4 & 3 & 3 & 3 & 4 & $\mathbf{3 3}$ \\
\hline Krajiški višeboj & 1 & 2 & 1 & 2 & 1 & 2 & 2 & 2 & 4 & 4 & 3 & 4 & 4 & $\mathbf{3 2}$ \\
\hline Seleuški višeboj & 1 & 2 & 1 & 2 & 1 & 1 & 1 & 2 & 4 & 3 & 3 & 3 & 3 & $\mathbf{2 7}$ \\
\hline $\begin{array}{l}\text { Plemenske } \\
\text { viteške igre }\end{array}$ & 1 & 2 & 1 & 2 & 1 & 2 & 2 & 2 & 4 & 4 & 3 & 4 & 3 & $\mathbf{3 1}$ \\
\hline $\begin{array}{l}\text { Seoska olimpijada } \\
\text { Sefkerin }\end{array}$ & 1 & 1 & 1 & 2 & 0 & 1 & 1 & 2 & 2 & 3 & 3 & 2 & 3 & $\mathbf{2 2}$ \\
\hline $\begin{array}{l}\text { Vojvođanska } \\
\text { olimpijada starih } \\
\text { sportova }\end{array}$ & 1 & 2 & 2 & 2 & 2 & 2 & 2 & 2 & 2 & 3 & 2 & 3 & 2 & $\mathbf{2 7}$ \\
\hline
\end{tabular}

Izvor: istraživanje autora

Dužijanca, Banatske šore, Lička olimpijada i Ovčarski dani u Kumanu (tj. igra činga) su manifestacije koje imaju značajnu istorijsku, estetsku, naučno-stručnu, edukativnu i društvenu vrednost i često predstavljaju predmet istraživanja etnologa, pedagoga, sociologa, turizmologa, stručnjaka iz oblasti sporta i fizičke kulture. Organizavanje ovih manifestacija ima i značajan uticaj na društvo i lokalnu sredinu u smislu negovanja i očuvanja starih običaja i etnografskih karakteristika pojedinih nacionalnih zajednica, kao i širenje kulturne i turističke ponude same destinacije. Organizatori većine manifestacija su uglavnom zavičajna udruženja, lokalna privredna društva i turističke organizacije i skoro sve imaju plan upravljanja, a i pogodnosti za različite vrste investicija. Pošto se pretežno održavaju na sportskim stadionima, vašarištima i drugim otvorenim prostorima, nemaju negativni uticaj velikog broja posetilaca, već naprotiv, imaju problem malog broja posetilaca i nedovoljne turističke potrošnje. Što se tiče osetljivosti i stanja reparacije, kod pojedinih manifestacija je prisutan problem modernizacije sportskih pomagala ${ }^{13}$, ali i očuvanje u originalnom obliku jednog broja tradicionalnih starih sportova (činga).

Prema oceni indikatora sektora menadžmenta manifestacije se mogu rasporediti u tri kategorije. Tako se $\mathrm{u} u$ kategoriji niska osetljivost/visoka kulturna vrednost nalazi samo Dužijanca (43 boda). U kategoriji srednje osetljivosti i srednje kulturne vrednosti nalazi se 12 manifestacija, među kojima prednjače Lička olimpijada (35) i

13 Npr. kod Banatskih šora u poslednje vreme se igra bejzbol palicama, ili kod narodnog višeboja takmičari su u trenerkama i patikama, a ne u karakterističnoj narodnoj nošnji, kod Seljačke olimpijade korišćenje traktora, proizvoda od gume i dr. 
Banatske šore (33 boda). U kategoriji niskog nivoa menadžmenta nalaze se tri manifestacije: Ovčarski dani (Ležimir, 20 bodova), Seljačka olimpijada (Mol, 15 bodova) i Seljački parti (Mokrin, 13 bodova).

$\mathrm{Na}$ osnovu prethodno izvršene analize postavili smo matricu tržišne privlačnosti/ robusnosti" kako bismo sproveli valorizaciju do kraja i utvrdili koje od manifestacija se izdvajaju po svom turističkom značaju (Tabela 5). Korelacijom parametara dobili smo da se u polju matrice $\mathrm{M}(1,3)$ nalazi Dužijanca i u polju $\mathrm{M}(2,3)$ se nalazi Lička olimpijada, čime se ove dve manifestacije izdvajaju po svom turističkom potencijalu i značaju za diverzifikaciju turističke ponude svojih destinacija. U polju matrice $\mathrm{M}(2,2)$ se nalazi najviše manifestacija, njih osam, koje odlikuje srednja vrednost indikatora kulturne značajnosti/robusnosti i srednja turistička privlačnost, tako da ih možemo posmatrati kao značajan turistički potencijal koji zahteva dodatna ulaganja, razvoj, promociju, kao i dodatnu brigu o očuvanju destinacije od prekomernog razvoja turizma koji bi mogao dugoročno da je ugrozi. U polju matrice $M(2,2)$ su se našle manifestacije: Seljačka olimpijada Vojvodine, Ovčarski dani (Sakule), Ovčarski dani (Kumane), Banatske šore, Krajiški višeboj, Seleuški višeboj, Plemenske viteške igre i Vojvođanska olimpijada starih sportova.

Tabela 5. Matrica tržišne privlačnosti/robusnosti

\begin{tabular}{|c|c|c|}
\hline Manifestacija & $\begin{array}{c}\text { Ostvareni bodovi } \\
\text { (trž. privlačnost/ robusnost) }\end{array}$ & Polje u matrici \\
\hline Dužijanca & $54 / 43$ & $M(1,3)$ \\
\hline Seljačka olimpijadaVojvodine & $26 / 25$ & $M(2,2)$ \\
\hline Seljački parti & $19 / 13$ & $M(3,1)$ \\
\hline Seljačka olimpijada Mol & $16 / 15$ & $M(3,1)$ \\
\hline Ovčarski dani Sakule & $28 / 31$ & $M(2,2)$ \\
\hline Ovčarski dani Kumane & $27 / 30$ & $M(2,2)$ \\
\hline Ovčarski dani Ležimir & $15 / 20$ & $\mathrm{M}(3,1)$ \\
\hline Ovčarski dani Obrovac & $16 / 21$ & $M(2,1)$ \\
\hline Ovčarski dani Čurug & $19 / 23$ & $\mathrm{M}(2,1)$ \\
\hline Banatske šore & $36 / 33$ & $M(2,2)$ \\
\hline Lička olimpijada & $53 / 35$ & $M(2,3)$ \\
\hline Krajiški višeboj & $36 / 32$ & $M(2,2)$ \\
\hline Seleuški višeboj & $30 / 27$ & $M(2,2)$ \\
\hline Plemenske viteške igre & $34 / 31$ & $M(2,2)$ \\
\hline Seoska olimpijada Sefkerin & $17 / 22$ & $\mathrm{M}(2,1)$ \\
\hline Vojvođanska olimpijada starih sportova & $30 / 27$ & $M(2,2)$ \\
\hline
\end{tabular}

Izvor: istraživanje autora 


\section{Zahvalnica}

Rad je deo istraživanja u okviru projekata 47007 III, 47027III, finansiranih od Ministarstva prosvete, nauke i tehnološkog razvoja Republike Srbije i projekta „Dokumentovanje i vrednovanje tradicionalnih sportskih igara kao elemenata nematerijalnog kulturnog nasleđa“, finansiranog od Ministarstva kulture i informisanja Republike Srbije.

\section{Zaključak}

Tradicionalne sportske igre su deo nematerijalne kulturne baštine naroda i prostora u kojima su nastale. Njihova vrednost je prepoznata ne samo u kulturološkom, etnografskom ili sociološkom smislu, već i kao važan segment turističke ponude koji unosi inovativnost $\mathrm{i}$ originalnost $\mathrm{u}$ tu ponudu i pokreće brojne aktere koji se do tada nisu uključivali u turizam. Ovde je poseban značaj dat mladima kao nosiocima igara ili njihovim organizatorima u najvećoj meri. Takođe, tradicionalne sportske igre afirmišu i seoske sredine u kojima se održavaju, što je još jedna dodatna vrednost u pravcu afirmacije nedovoljno uključenih prostora $\mathrm{u}$ turistička kretanja.

Tradicionalni stari sportovi u Vojvodini su, s turizmološkog aspekta, najčešće deo turističke ponude lokalnog i regionalnog karaktera,kao manifestacije koje imaju određenu turističku vrednost. Valorizacijom je utvrđeno da se posebno izdvajaju Dužijanca i Lička olimpijada koje su turistički veoma privlačne na nacionalnom nivou, kao i za posetioce i učesnike iz inostranstva $(\mathrm{BiH}$, Hrvatske i Crne Gore). Ovčarski dani (Sakule), uz Seosku olimpijadu (Sefkerin), su uz eko i filmski turizam značajni segmenti turističke ponude opštine Opovo (posebna atrakcija trka magaraca), ali nemaju privlačnu snagu samostalnog proizvoda. Autori su kroz istraživanje uočili da je kod većine manifestacija prisutan problem nepovezanosti i nedostatka saradnje $s$ turističkim organizacijama i agencijama u bliskom prostoru, iako postoje uslovi da kroz ruralni turizam manifestacije budu predstavljene kao deo turističke ponude opštine ili kao komplementarni sadržaji najčešće oskudnoj kulturnoj ponudi sela. Banatske šore koje, iako su reprezentativne i predstavljaju retkost na destinaciji, nisu sastavni deo turističke ponude grada Zrenjanina, kao ni Vojvođanska olimpijada starih sportova (Bačko Gradište) koja je slabo promovisana od Turističke organizacije opštine Bečej. Ovčarski dani (Kumane) imaju lokalni karakter, privredno-turistički, ali i turistički potencijal zbog tradicionalnog starog sporta činga, što bi trebalo da prepozna Turistička organizacija Novog Bečeja i da snažnije promoviše ovu manifestaciju pre svega na stranom tržištu. Ostale manifestacije imaju svoj turistički potencijal, ali je nedovoljna saradnja stejkholdera na lokalnom i pokrajinskom nivou.

Rezultat navedenog može da bude i pravljenje kulturne rute „Tragom starih sportova“ ili „Put tradicionalnih sportova i igara“, čime bi se dodatno promovisao seoski, kulturni i sportsko-manifestacioni turizam $\mathrm{u}$ Vojvodini, a tradicionalne sportske igre bi činile bitan element diverzifikacije turističke ponude i afirmacije seoskih sredina što bi dugoročno ekonomski valorizovalo ovu ponudu i osnažilo seoske sredine.

\section{Literatura}

Bale, J. (2003) Sport geography.Second edition. London:Routledge.

Bjeljac, Ž, Terzić, A, Curčić, N. (2014) Turizmološka valorizacija nematerijalne kulturne baštine Srbije po Hilari Du Kros metodi. Etnoantropološki problemi 9 (1), 195-217. 
Bjeljac, Ž. (2010)Turističke manifestacije u Srbiji. Posebna izdanja br. 82, Beograd: Geografskiinstitut „Jovan Cvijićc SANU.

Bjeljac,Ž., Brankov, J. (2019) Traditional sport games aspart oftouristoffer (ppt, lecture on event Vojvodina olimpic game in old sports, Bačko Gradište, 17.08.2019.)

Bjeljac, Ž., Brankov, J. (2010) Turistička manifestacija Ovčarski dani, Hotellink 1314, 654-661.

Bjeljac, Ž., Ćurčić, N. (2008) Evaluating Duzijanca as the tourist product of Subotica. In: Tourism \& Hospitality Industry 2008: New Trends in Tourism and Hospitality Management. Proceedings /Ivanović, Z. (ed.). 19th biennal international congress.7-9. maj 2008. Opatija.Opatija: Faculty for Tourism and Hotel Management, University Rijeka, 267-278.

Bjeljac, Ž., Ćurčić, N. (2017) Tradicionalne narodne sportske igre i veštine u Srbiji kao element turističke ponude Srbije. U: „Sport, recreation, helth", The second international conference, 12-13. maj 2017. Beograd. Beograd: Visoka sportska i zdravstvena škola, 36-42.

Bjeljac, Ž., Ćurčić, N., Ivolga, A. (2017)Tourismological classification of sporting events, J. Geogr.Inst. Cvijic. 67(1), 53-67.

Bjeljac, Ž., Terzić, A. (2016)Migracije na teritoriji Vojvodine 1945-1948. Uzroci i demografske posledice. U:Janjetović Z.1945.Kraj ili novi početak?Tematski zbornik radova br. 13. Beograd: Institut za noviju istoriju Srbije, Muzej žrtava genocida, 375-402.

Bjeljac, Ž., Terzić, A., Lović, S. (2015)Nematerijalno kulturno nasleđe u Srbiji kao turistički brend, Turističko poslovanje, 15(2), 53-61.

Božović, R.R. (2008) Slobodno vrijeme i igra, Sociologija 1, 97-109.

Brewster, M., Connell, J., Page, S. J. (2009) The Scottish Highland Games: evolution, development and role as a community event.Current issue in tourism, 12(3),
271-293.

Bronikowska, M., Petrovic, L., Horvath, R., Hazelton, L., Ojaniemi, A., Alexandre, J., Silva, C. F. (2015) History and Cultural Context of Traditional Sports and Games in Selected European Countries. 1-19 [online] Frankfurt/Main: TAFISA Recall, Germany Dostupno na: http:// www.tafisa.net [11.10.2019.]

Cvetković, J. (1982)Stari sportovi Jugoslavije. Osijek: Štampa.

Čačić, M., Šimunđa, S., Matasović, M. (2013) Uloga lipicanaca u razvoju hrvatskog konjičkog sporta.Stočarstvo 67(1), 17-22.

Devine, A., Devine, F. (2005) Sports tourism marketing Ireland's best kept secret-the Gaelic association. The Irish Journal of Management (Special Issue) 1 (1), 7-32.

Du Cros, H. (2000). Planning for Sustainable Cultural Heritage Tourism in Hong Kong. Final Report to the Lord Wilson Heritage Trust Council, SAR.

Du Cros, H., Mc Kercher, B. (2015) Cultural tourism. Second edition, London:Routledge.

Edwards, K. (2012) A Typology of the Traditional Games of Australian Aboriginal and Torres Strait Islander Peoples. Ram Skulls Press, Esk, Australia. ISBN 9780-9872359-0-9 [online] Dostupno na: https://eprints.usq.edu.au/24916/12/ Edwards_typology_PV.pdf [05.09.2019.]

Eichberg, H. (1995) Problems and future research in Sports sociology: A revolution of Body Culture. Int. Rev. for soc of sport 30(1), 1-19.

Hadžić, O., Stojaković, G., Herman-Milinković, K., \& Ivanović, I.(2005) Kulturni turizam. Novi Sad: PMF- Departman za geografiju, turizam i hotelijerstvo.

Hajra, V. (2015)Role of Indian folk culture in promotion of tourism in the country. Indian journal of research 4(2), 231-235.

Hedegard, D. (2013) Blackness and experience in omnivorous cultural consumption: Evidence from the tourism of capoeira in Salvador, Brazil. Poetics 41(1), 1-26. 
Krasilnikov, V. (2006) Traditional games and competitions in original physical training of Siberian indigenous population. Revista Digital - Buenos Aires, Año 11 - No 102 - Noviembre de 2006. [online] Dostupno na: http://www.efdeportes. com[25.09.2019.]

Khan K. A., Tluehan B. (2019) UNESCO traditional sports and games. The Russian Journalof Physical Education and Sport. 2019; 14(2): 5-8. [online] Dostupno na: https://cyberleninka.ru/article/n/ unesco-traditional-sports-and-games/ viewer[08.12.2019.]

Linaza, M., Kieran, M., O'Connor, N. E. (2013-2015) Traditional Sports and Games: A New Opportunity for Personalized Access to Cultural Heritage. 1-6, The RePlay Project. [online] Dostupno na: http://ceur-ws.org/Vol-997/patch2013_ paper_2.pdf [12.10.2019.]

Liponski, W. (2003) World Sports Encyclopaedia. Poznań: Publishing House Atena.

Marjanović, V. (2005) Tradicionalne dečije igre u Vojvodini. Novi Sad: Matica Srpska.

Миленковић, J., (2018) Валоризација културних туристичких вредности градског језграНиша по моделу Хилари ду Крос. Гласник СГД 98(2), 147-173.

Novković, N., Mutavdžić, B., Szabo, E., Szabo, A. (2009) Komparativna analiza stočarstva u Vojvodini i Mađarskoj. Agroekonomika 41-42, 45-52.

Prabucki, B. (2014) Basque festival Aste Nagusia as an interesting example of cultural and sport tourism attraction. II International Conference of Tourism, Hospitality and Recreation, Poznan, 19th-21st May 2014, New trends in tourism research - a Polish perspective, part 1-cultural tourism,80-97 [online] Dostupno na: http://www.icthr.byd.pl/ userfiles/files/Student_Monograph_ New\%20Trends\%20in\%20Tourism\%20 Research_final_versio [24.09.2019.]
Renson, R., Cramer, E., Vroede, E. (1997) Local heroes. Beyond the stereotipe of the participants in traditional games. Internal review for the sociology of sport 32 (1), 59-68.

Sogawa, T. (2006) Ethnic sport, its concept and research perspectives.International journal of Sport and Health science 4, 96-102.

Станојловић, А., Ћурчић, Н. \& Павловић, Н. (2010). Туристичка валоризација локалитета «Лазарев град» у Крушевцу. 3борникрадова Географског института "Јован Цвијић» САНУ, 60(2), 77-92.

Stojaković, I. (2019) Hurling i irski nogomet - više od sporta. [online] Dostupno na: https://igor.stojakovic.net/hr/hurling-i-irski-nogomet-gaa-hurling-i-gaa-football-vise-od-sporta/[pregledano 14.12.2019].

Šiljak, V. (2007) Istorija sporta. Beograd: Fakultet za menadžment u sportu „Braća Karić“.

\section{Web izvori:}

Asocijacija „Sport za sve“ Beograd [online]. Dostupno na: http://www.sportzasvebeograd.rs/index.php/sr/53-sport-for-all/ ostalo/166-festival-tradicionalnih-narodnih-vestina [pregledano 14.11.2019.]

BAP Vesti [online]. Dostupno na: http:// backapalankavesti.com/odrzani-ovcarski-dani/[pregledano29.10.2019.]

Banatske šore [online]. Dostupno na: http://banatskesore.com [pregledano 23.03.2017.]

Dužijanca [online]. Dostupno na: facebook.com/Du\%C5\%BEijanca[pregledano 28.10.2019.]

Glas Opova [online]. Dostupno na: www. glasopova.rs/[pregledano 28.10.2019.]

Lički višeboj [online]. Dostupno na: www.lickiviseboj.com [pregledano 27.03.2017.]

Moja Bačka Topola [online]. Dostupno na: http://mojabackatopola.rs/mali-idos/odrzane-plemenske- [pregledano 
29.10.2019.]

Opština Alibunar [online].Dostupno na: www.alibunar.org.rs/novosti/seleuski -viseboj[pregledano29.10.2019.]

Radio-televizija Vojvodine [online]. Dostupno na: www.rtv.rs/zivot/magazin/ seljacki-parti-u-mokrinu[pregledano28.10.2019.]

Sremske novine [online]. Dostupno na: www.sremskenovine.co.rs/odrzani ovcarski-dani[pregledano29.10.2019.]

TAFISA - The association for international sport for all [online]. Dostupno na: http://www.recallgames.com/games/7 [pregledano 14.12.2019.].

Turistička organizacija Apatin[online].Dostupno na: https://www.apatin.org.rs/kalendar-desavanja/licka-olimpijada[pregledano 29.10.2019.]

Turistička organizacija opštine Žabalj [online]. Dostupno na: www.facebook.com/TooZabalj/posts//[pregledano29.10.2019.]

Televizija Rubin [online]. Dostupno na: tvrubin.rs/krajiski-viseboj-u-banatskom-velikom-selu/[pregledano29.10.2019.]

UNESCO [online]. Dostupno na: http:// www.unesco.org/new/en/social-and-human-sciences/themes/physical-education-and-sport/traditional-sports-and-games/[pregledano 25.10.2019.]

Vajdaság Ma hírportál[online].Dostupno na: www.vajma.info/cikk/Backa-Topola -Vojvodanska-seljacka-olimpijada[pregledano28.10.2019.]

Vodič kroz turističke manifestacije [online]. Dostupno na: www.manifestacije.co$\mathrm{m}$ [pregledano27.03.2017.]

WEBINFO [online]. Dostupno na: www. webinfo.rs/info/37-novi-becej/-ovcarstva-kumane [pregledano28.10.2019.] 